\title{
Dramatic budget increase for hepatitis treatment in federal prisons
}

n Cite as: CMAJ 2017 August 14;189:E1052. doi: 10.1503/cmaj.1095468

Posted on cmajnews.com on July 27, 2017.

$\mathbf{T}$ here will be a vast increase in spending on treatment for the estimated 2700 federal inmates infected with hepatitis $\mathrm{C}$ virus ( $\mathrm{HCV})$. Correctional Service Canada (CSC) has a treatment budget for 2017-18 of $\$ 16.5$ million, nearly four times the amount budgeted in 2010, according to Ivan Zinger, the Correctional Investigator of Canada.

"This is a story of good leadership at the federal level," said Zinger.

In 2015, Zinger called on CSC to expand HCV treatment as an investment in public health. He credited CMAJ for "important work that kept the pressure on," referring to a series of news articles, starting in 2012, on HCV treatment rates in prisons.

The number of inmates started on HCV treatment doubled, to 606, between 2015 and 2016, said Zinger. Another 121 began treatment in April and May of this year. "At this rate, CSC could start over 1000 offenders on curative HCV therapies" in 2017, he said.

CSC's new approach to HCV treatment can be credited to the introduction of new direct-acting antivirals, bulk purchasing agreements with drug makers, and updated treatment guidelines by the Canadian Association for the Study of the Liver, according to Jennifer Wheatley, assistant commissioner of health services for CSC.

"All inmates diagnosed with hepatitis C are now eligible for treatment," she said.

Several hepatitis treatment specialists said they are both startled and pleased by CSC's new approach. "We're blown

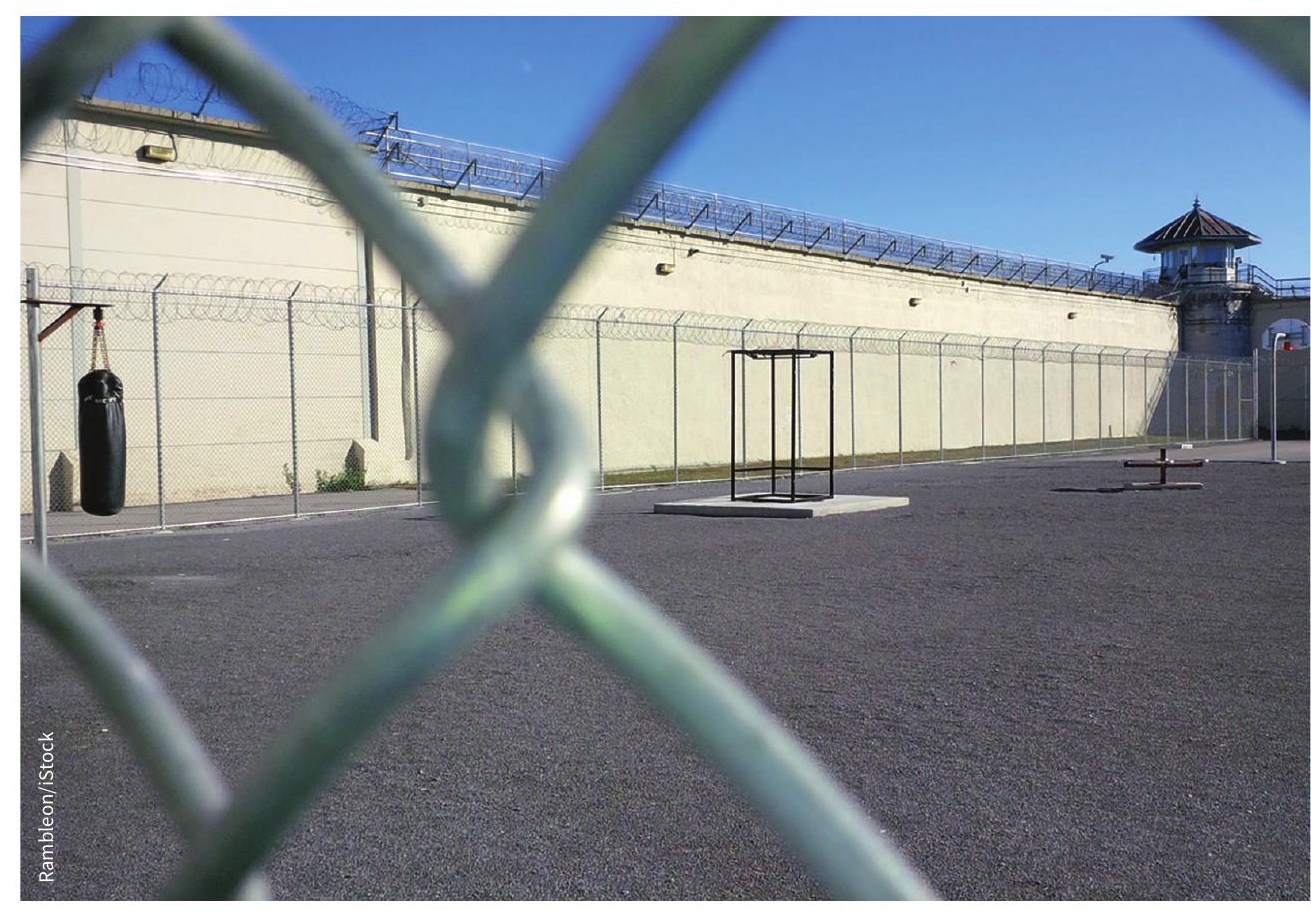

All federal inmates with $\mathrm{HCV}$ are eligible for treatment.

away," said Shelley Beckstead, a nurse with the Street Health Centre in Kingston, home to three federal prisons. "They seem to be treating everyone."

The CSC "is now doing an incredible job making the new HCV drugs available," said Zachary Grant, the federal HCV program coordinator for the Prisoners' HIV/ AIDS Support Action Network.

According to Dr. John Farley, who treats HCV patients in several federal prisons, the CSC's new approach to treating HCV is a "bold step toward hepatitis eradication."

Both Grant and Farley suggested that the managers of provincial prisons should follow the CSC's lead. That isn't to say, however, that the CSC's work on HCV management is complete.

Nursing cutbacks are hindering the administering of $\mathrm{HCV}$ treatment, argued Farley. Those who have been treated and cured are at high risk of reinfection because of a lack drug addiction counselling and safe-needle programs.

"Needle exchange programs and addiction treatment should be viewed as crucial components of the HCV treatment program," said Farley. "Otherwise, reinfection will be its Achilles heel."

Paul Webster, Toronto, Ont. 